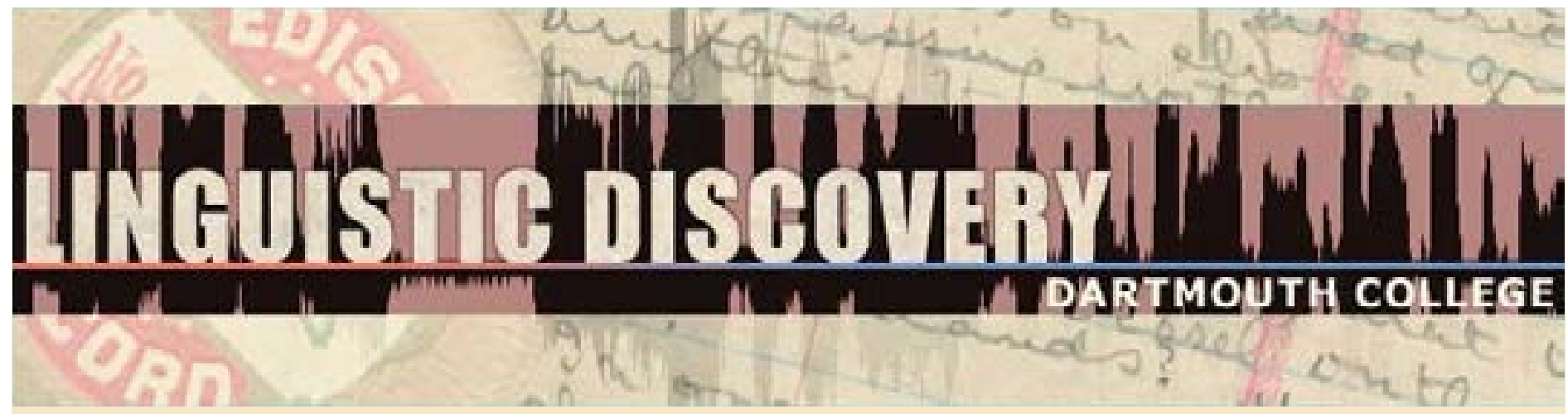

\begin{tabular}{|l|}
\hline Volume 10 \\
Issue 1 \\
2012 \\
\hline
\end{tabular}

\title{
Degrees of Clause Cohesion: Complementation and Subordination in Chiapas Zoque
}

Jan Terje Faarlund

University of Oslo

doi: 10.1349/PS1.1537-0852.A.406

url: http://journals.dartmouth.edu/cgi-bin/WebObjects/ Journals.woa/1/xmlpage/1/article/406

Linguistic Discovery

Published by the Dartmouth College Library Copyright to this article is held by the authors. ISSN 1537-0852 linguistic-discovery.dartmouth.edu 


\title{
Degrees of Clause Cohesion: Complementation and Subordination In Chiapas Zoque
}

\author{
Jan Terje Faarlund \\ University of Oslo
}

Zoque exhibits various degrees of interclausal cohesion or types of embedding: juxtaposition, use of conjunctions, subordination with complementizers, and synthetic subordination by head marking. These various types of subordination are used for different clause types, such as complement clauses, adverbial clauses, and relative clauses, and they are for the most part native and precolonial in origin. Relative clauses may be formed by external or internal relativization. The former type corresponds to constructions with a nominal head and a clausal modifier, where the relativized element inside the clause is invisible or represented by a relative pronoun. The latter type corresponds to constructions where the relativized element is overtly present inside the clause.

\section{Introduction}

The language referred to as Chiapas Zoque belongs to the Zoquean branch of the Mixe-Zoque family, all spoken in Southern Mexico. It has a very brief history as a literary language. Except for religious texts and a few collections of folkloristic material, the use of the language in writing started in the mid 1990's. On the other hand, Zoque, as any other indigenous language of Mexico or Central America, has been under heavy influence from Spanish. In the area of sentence complementation and subordination, however, whatever complexity there is seems to a large extent to be native and precolonial.

Zoque is a morphologically ergative language, and in part even syntactically ergative, except that there is not always a correspondence between the absolutive argument and the pivot (for details, cf. FAARLUND 2011). The ergative case of full nominals is marked with the clitic element 'is, while the absolutive is zero marked. In pronouns both cases are marked morphologically. In addition to those two grammatical cases, there is a series of semantic cases, including local cases.

A typical morphological feature of the language is that such categories as are expressed by means of inflection and affixation in other languages may be expressed by clitics in Zoque. Clitics typically have a phrase as their domain. A clitic is characterized by its ability to attach to different categories of hosts, and by not always being required. In this way they differ from affixes. Clitics are always enclitics in Zoque, they follow their host and its suffixes. Noun phrase clitics express case and number, and they attach to the last word of the phrase (which is also in most cases the noun). Clausal clitics attach to the head of the clause, and are of three different kinds: clitics marking subordination, pronominal clitics (first person only), and various circumstantial clitics. In this paper, I will only be concerned with clausal clitics of subordination. ${ }^{1}$ The notion of head of a clause therefore needs a definition. Basically, the head is the verb. The verb may, however, be preceded by an auxiliary, in which case the auxiliary governs the verb and is the head of the clause and the host of clausal clitics. The verb or the

\footnotetext{
${ }^{1}$ For further details on the other types of clitics, see Faarlund 2004 and 2012.
} 
auxiliary may in turn be preceded by an uninflected word, called preverb; this may either express progressive aspect, or it may be a negation. If there is a preverb in the clause, it functions as its head. Finally, if there is an indepentent complementizer word, it is the head of the clause.

Zoque exhibits four kinds of subordination strategies, with different degrees of cohesion or entrenchment.

- Juxtaposition

- Free word complementizer or wh-word

- Cliticized complementizer

- Monoclausal construction

At one extreme is simple juxtasposition; then there is subordination by means of an independent introductory word, which may be a complementizer or an interrogative word or phrase ( $w h$ word); then there are synthetic constructions where the complementizer is cliticized to the head of the clause; and finally we find monoclausal relative constructions, where the head is incorporated into the relative clause (internal relativization). This latter type has been further grammaticalized into focus constructions and possessive constructions. These various categories were also present in the traditional pre-colonial language before the contact with Spanish, as can be witnessed from the very earliest descriptions of the language by the first colonizers and missionaries, and from the earliest translations of religious texts. As we will see, Zoque has native complementizers and other grammatical means of subordination.

In this paper I will give examples and illustrations of each of these subordination strategies, starting with a brief description of complement clauses in section 2 and adverbial clauses in section 3. Both of those clause types exhibit a variation in subordination strategies. In section 4 , which is the main body of the paper, I will demonstate how relative clauses must be analysed as either external or internal, the latter representing the ultimate degree of cohesion. Section 5 is the conclusion, pulling the different data together.

\section{Complement Clauses}

Verbs of perception (seeing, hearing etc.) may take object clauses without a complementizer.

$\begin{array}{lllllll}\text { Te'yi midu'muy } & \text { 'yisi } & \text { te' } & \text { tseke } & \text { nü'amuy } & \text { myidu } \\ \text { te'yi min-u=am='un } & \text { y-'is-E } & \text { te' } & \text { tseke } & \text { nü=am='un } & \text { y-min-u } \\ \text { then } & \text { INC-CP=PERF=EV } & \text { 3A-see-DEP } & \text { DET } & \text { tortoise } & \text { PRG=PERF=EV } & \text { 3A-come-PG } \\ \text { 'Then he realized that the tortoise was coming' } & \text { (Sabiduría } & \text { 14, 62) } & \end{array}$

(2)

$\begin{array}{llllc}\text { Midu'un } & \text { myane } & \text { nü'amun } & \text { kyojkxaju } & \text { aydun } \\ \text { mit-u='un } & \text { y-man-E } & \text { nü=am='un } & \text { y-koks-yaj-u } & \text { aydun } \\ \text { INC-CP=EV } & \text { 3A-hear-DEP } & \text { PRG=PERF=EV } & \text { 3A-knock-3PL-PG } & \text { door }\end{array}$

'She suddenly heard that someone knocked on the door' (Bolom 247)

These constructions have very much the same function as English small clauses governed by a verb of perception, as in 'She saw the tortoise coming'. Syntactically they are very different, however. Zoque does not have non-finite verbs; the second verb in each example, myidu and 
kyojkxaju, both have person inflection and a mood-aspect suffix. Furthermore, there is no indication that the subject of the second verb has an object role relative to the preceding verb (as in English 'She saw him coming'). In (1) the second subject is in the absolutive, but that is because it is the subject of the following intransitive verb -- with absolutive agreement -- not because it is the object of the preceding verb. Accordingly, in (2), the second verb has ergative agreement.

More commonly, however, the complements of such verbs are introduced by the complementizer ke (<Spanish que), as in (3). This is now also the general rule with verbs which mean to say, tell, think, want, know, etc., as in (4) and (5).

$\begin{array}{llll}\text { Y-ijsu'munn } & \text { ke } & \text { suñimü } & \text { ijtu } \\ \text { y-'is-u=am='un=te } & \text { ke } & \text { suñi=mü } & \emptyset \text {-'it-u } \\ \text { 3A-see-CP=PERF=EV } & \text { C } & \text { good=LOC } & \text { 3B-be-CP }\end{array}$

'He saw that he was in a good place' (Historia 70)

$\begin{array}{llllllll}\text { (4) Yüti } & \text { ndeke } & \text { nübyajpa } & \text { ke } & \text { makamun } & \text { püngedi } & \text { yü } & \text { ame } \\ \text { yüti } & \text { ndeke } & \varnothing \text {-nüm-yaj-pa } & \text { ke } & \text { man-pa=am='un } & \varnothing \text {-pün-ke’t-E } & \text { yü' } & \text { ame } \\ \text { now } & \text { also } & \text { 3B-say-3PL-ICP } & \text { C } & \text { FUT-ICP=PERF=EV } & \text { 3B-erupt-REP-DEP } & \text { PRX } & \text { year }\end{array}$ 'Now they also say that it is going to erupt again this year' (Ocotepec)

(5) Nüdi'ande

$$
\text { mjamubü }
$$

$\mathrm{nu}=\mathrm{ti}=\mathrm{am}=\mathrm{te}$

$\mathrm{m}-\mathrm{jam}-\mathrm{u}=\mathrm{pü}$

ke jomide

ta'nbabü

m'ame

PRG=LIM=PERF=PRED

2A-remember-G=REL

ke jomi=te

$\varnothing$-ta'n-pa=pü

m-ame

'Do you remember that tomorrow is your birthday' (Sabiduría 7, 29)

This then looks like a situation where a formal mark of subordination was borrowed from the colonizer language where none existed in the native language. This is not correct, however. Zoque did not lack complementizers before the colonization, either. One native complementizer is $u k a$, which is found in the oldest Zoque texts, from the $17^{\text {th }}$ century, mostly in the sense of 'if' or 'or'. Today, too, it most often translates as 'if', both as a conditional and in indirect questions (cf. section 3.3), but it is also used to introduce complements of verbs which imply doubt or insecurity.

$\begin{array}{lllllll}\text { Ji'na'ajk } & \text { myuxe } & \text { uka } & \text { maka } & \text { püwi } & \text { te' bolkan } \\ \text { ji'n=na'ak } & \text { y-mus-yaj-E } & \text { uka } & \text { man-pa } & \varnothing \text {-pün-E } & \text { te' } & \text { bolkan } \\ \text { NEG=PST } & \text { 3A-know-3PL-DEP } & \text { if } & \text { FUT-ICP } & \text { 3B-erupt-DEP } & \text { DET } & \text { volcano } \\ \text { 'They did not know whether the volcano was going to erupt' (Ocotepec) }\end{array}$

(7) Te' pobrebü gyomo'is kyomübya'ujn

te' $\quad$ pobre $=$ pü $\quad \mathrm{y}$-yomo $=$ 'is $\quad \mathrm{y}$-komüy-pa $={ }^{\prime} u \eta$

DET poor $=$ REL $3 \mathrm{~A}-$ wife $=\mathrm{ERG} \quad 3 \mathrm{~A}$-assume $-\mathrm{ICP}=\mathrm{EV}$ 


$\begin{array}{lllll}\text { uka nüde } & \text { gyojsubü } & \text { te' } & \text { jyaya } \\ \text { uka } & \text { nü=te } & \text { y-yos-u=pü } & \text { te' } \quad \text { y-jaya } \\ \text { if } & \text { PRG=PRED } & \text { 3A-work-PG=REL } & \text { DET } & \text { 3A-husband } \\ \text { 'The poor wife assumed that her husband was working' (Historia 74) }\end{array}$

The most important native complementizer is $w a$ ' $a$, which also goes back to the earliest texts. It is followed by the subjunctive form of the verb, and it serves various functions. It may introduce complements of verbs meaning 'want', 'order', or 'tell someone to'.

(8) Ji'namüjt

suni wa'a pyüku

ji'n=am='üj-t

n-sun-E wa'a y-pün-u

NEG=PERF=PRO1-ERG 1A-want-DEP SC 3A-erupt-SUB

'I don't want it [the volcano] to erupt' (Ocotepec)

(9) Te' gyomo'is myajkmaku'ujn wa'a maku gyojse

te' $\quad \mathrm{y}$-yomo='is $\mathrm{y}$-makmak- $\mathrm{u}={ }^{\prime}$ un wa'a may-u $\mathrm{y}$-yos-E

DET 3A-wife=ERG 3A-demand-CP=EV SC go-SUB 3A-work-DE

'His wife demanded that he went to work' (Historia 74)

The complementizer wa' $a$ is also used to introduce clausal subjects.

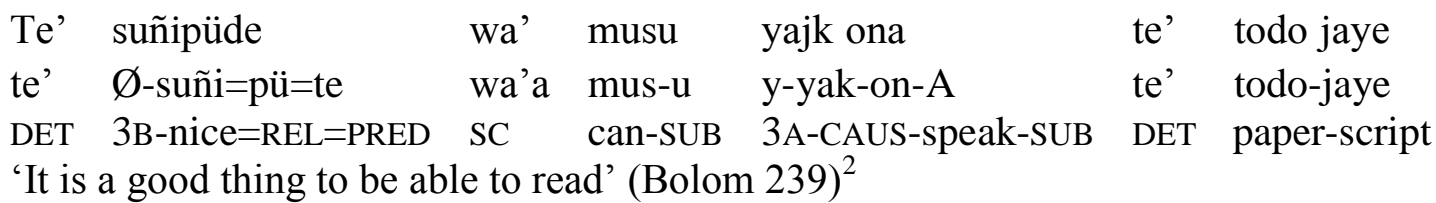

$\begin{array}{llll}\text { (11) Wa'a } & \text { Sapatista'aju } & \text { ji'nde } & \text { kowa } \\ \text { wa'a } & \varnothing \text {-sapatista-'aj-u } & \text { ji'n-te } & \text { kowa } \\ \text { SC } & \text { 3B-sapatista-INCV-SUB } & \text { NEG=PRED } & \text { crime } \\ \text { 'Being a Zapatista is not a crime' } & \end{array}$

The introduction of the Spanish ke thus did not create new syntactic patterns, it just expanded the inventory of existing complementizers. Nor did it replace any of the old ones (as far as we know), it just optionally replaced the null complementizer.

\section{Adverbial Clauses}

\subsection{Cliticized Complementizers}

Adverbial clauses expressing time, place, cause, or manner may be marked by a clitic attached to the head of the clause. This type is clearly native; it has no forebears in any colonizer language.

\footnotetext{
${ }^{2}$ The Zoques show an impressive creativity when it comes to coining native words for new concepts. Thus to read is to 'make the paper talk'.
} 
The complementizer clitics for place and manner are identical to semantic case endings; the clitics for time and cause are separate clitics not used in other functions.

The head of a temporal clause may carry the clitic ' $k$ 'when', as in (12), or the complex clitic seyomo 'until', as in (13).

$\begin{array}{llll}\text { maka'kam } & \text { pü'naje } & \text { te' } & \text { ngomi } \\ \text { may-pa='k=am } & \emptyset \text {-pün-'aj-E } & \text { te' } & \text { n-komi } \\ \text { FUT-ICP=TSUB=PERF } & \text { 3B-man-INCV-DEP } & \text { DET } 1 \text { A-saint } \\ \text { 'then when our Lord is going to be born' } & \text { (Ocotepec) }\end{array}$

$$
\begin{array}{llll}
\text { De tsujk } & \text { ujku'un } & \text { ükbajkujsenomo } \\
\text { te' tsuk } & \emptyset \text {-'uk-u='un } & \varnothing \text {-'ükpak-u=senomo } \\
\text { DET } & \text { mouse } & \text { 3B-eat-CP=EV } & \text { 3B-fall.asleep-CP=until } \\
\text { 'The mouse ate until he fell asleep' (Kak 17) }
\end{array}
$$

In (12) the clitic is attached to the future auxiliary maka, and followed by the perfective clitic am. In (13) there is no auxiliary in the subordinate clause, therefore the clitic is attached to the main verb ükbajku 'fell asleep'.

The head of a causal adverbial clause is marked by the clitic aykü, as in (14), where it is attached to the verb ndochüjkpa 'you abuse me'.

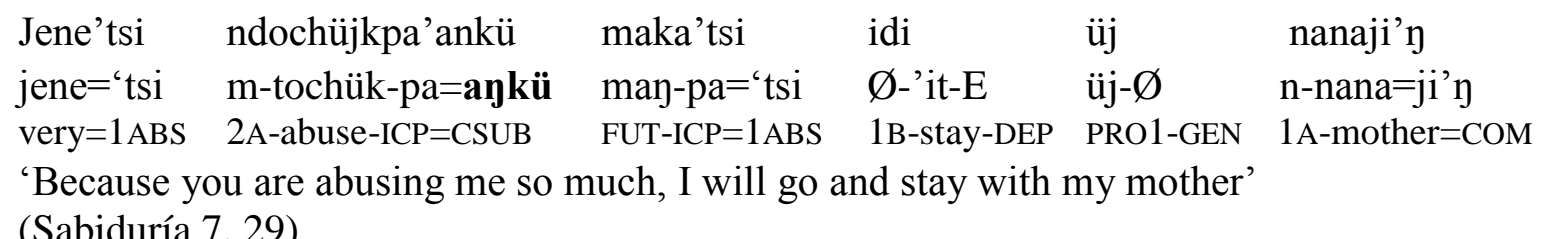

Clauses expressing the location of an event, corresponding to headless adverbial relatives with 'where', are marked by the locative case ending mü on the head, as in (15), where the case clitic is on the main verb ijtyaju 'was, stayed'.

$\begin{array}{lll}\text { Nu'ku } & \text { ijtyajumü } & \text { te'dam } \\ \varnothing-n \text { ' }^{\prime} \mathrm{k}-\mathrm{u} & \varnothing \text {-'it-yaj-u=mü } & \text { te'=tam } \\ \text { 3B-arrive-CP } & \text { 3B-be-CP=LOC } & \text { DET-PL }\end{array}$

'He arrived at where they were' (Bolom 267)

Clauses expressing manner are marked by the similative case endig se, as in (16), where the case clitic is attached to the verb.

$$
\begin{aligned}
& \text { Chamjayu'un ngyomo te' mabaxüyuse } \\
& \text { y-tsam-jay-u='un } \quad y \text {-yomo te' mabax-'üy-u=se } \\
& \text { 3A-say-APP-CP=EV 3A-wife DET dream-V-CP=SIM } \\
& \text { 'He told his wife how he had dreamt' (Bolom 264) }
\end{aligned}
$$




\subsection{Complementizer Word}

Another way of marking a subordinate clause is by means of a free word complementizer at the beginning of the clause. As we have seen above, Zoque possesses two common native complementizers: $u k a$ 'if', and $w a$ ' $a$ 'in order to'.

$\begin{array}{llllll}\text { Uka } & \text { ji'nüi } & \text { mbade } & \text { yüti'angüdi } & \text { makatsi } & \text { ka'e } \\ \text { uka } & \text { ji'n='üj-t } & \text { n-pa't-E } & \text { yütiangü=ti } & \text { man-pa='tsi } & \varnothing-k a '-E \\ \text { if } & \text { NEG=PRO1-ERG } & \text { 1A-find-DEP } & \text { now=LIM } & \text { FUT-ICP=1ABS } & \text { 1B-die-DEP }\end{array}$

'If I don't find it at once I am going to die' (Sabiduría 14, 61)

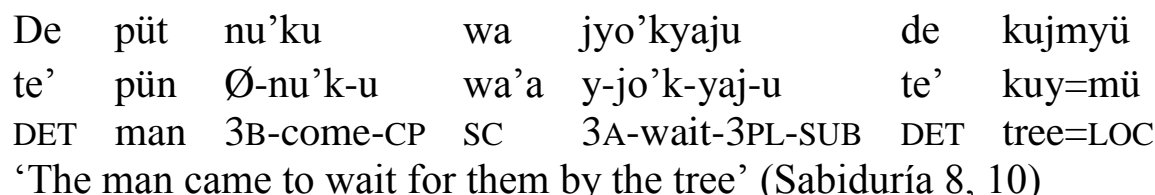

\subsection{Interrogative Word}

An interrogative pronoun or adverb may be used to introduce indirect questions, as in (19) and (20).
Dyosis iyisu'un
tiyü chüjku
dyos='is $\quad \mathrm{y}$-'isu='un
tiyü $\quad \mathrm{y}$-tsük-u
God=ERG 3A-see-CP=EV what 3A-do-CP
'God saw what he did' (Bolom 257)

$\begin{array}{llllll}\text { Te ndxibu'is } & \text { myuspa } & \text { judü } & \text { ijtu } & \text { nü' } \\ \text { te' } & \text { n-chibu='is } & \text { y-mus-pa } & \text { judü } & \emptyset \text {-it-u } & \text { nü' } \\ \text { DET } & \text { M-lamb=ERG } & \text { 3A-know-ICP } & \text { where } & \text { 3B-be-CP } & \text { water } \\ \text { 'The lamb knew where there was water' (Sabiduría 14, 61) }\end{array}$

Interrogative words are also used to introduce a kind of headless relatives ('whatever, anywhere'), as in (21). Besides the locative clauses exemplified in (15), with a case clitic on the head of the clause, adverbial relatives may also be introduced by an interrogative word, as in (22).

$$
\begin{aligned}
& \text { Wijtpa'ujn-na'ajk tumü püt mañabü } \quad \text { yempe judü byurroji'n } \\
& \varnothing \text {-wit-pa='un=na'ak tumü pün maña=pü yempe judü y-burro=ji'n } \\
& \text { 3B-walk-ICP=EV=PST one man clever=REL any } \quad \text { where } 3 \text { Adonkey=COM } \\
& \text { 'A clever man was walking anywhere with his donkey' (Historia 78) }
\end{aligned}
$$
Yü'se tujku
tumnaka
Chiapajsis
kyojame'omo
kupngu'y
yü'=se $\quad \varnothing$-tuk-u
tumü-naka
$\mathrm{PRX}=\mathrm{SIM}$
one-time
chiapas $=$ 'is
$\mathrm{y}$-kojame $={ }^{\text {'omo }}$
kupkuy
Chiapas $=$ GEN 3 A-interior $=$ LOC village 
$\begin{array}{llll}\text { judü } & \text { tsapndüjpa } & \text { te' } & \text { ode } \\ \text { judü } & \varnothing \text {-tsam-tüj-pa } & \text { te' } & \text { ode } \\ \text { where } & \text { 3B-speak-PAS-ICP } & \text { DET } & \text { language }\end{array}$

'This happened once in a village in Chiapas where they speak the language'

(Sabiduría 5, 23)

This kind of clause is therefore formally identical to indirect phrasal questions. Whether it is one or the other depends on the matrix verb or on the context.

\subsection{Spanish Complementizers}

Several complementizers of Spanish origin are used, especially in the spoken language. The most common ones, alongside que discussed above, are porke 'because', ayke 'although'(< aunque), komo 'as', kuando 'when', astake 'until' (< hasta que), anteske 'before' (< antes que).

$\begin{array}{llllll}\text { Yüti } & \text { komo } & \text { müjamüjtside, } & \text { ijtu'a } & \text { üj } & \text { ngipsokuy } \\ \text { yüti } & \text { komo } & \varnothing \text {-müja=am='üj-tsi=te } & \emptyset \text {-ijt-u=am } & \text { üj- } \varnothing & \text { n-kipso-kuy } \\ \text { now as } & \text { 1B-big=PERF=PRO1-ABS=PRED } & \text { 3B-be-CP=PERF } & \text { PRO1-GEN } & \text { 1A-think-N } \\ \text { 'Now that I am big, I am able to think' (Ocotepec) } & & \end{array}$

$\begin{array}{lllll}\text { Porke } & \text { kuando tütmba, } & \text { tyütmbü'ba } & \text { puro tumi'n } \\ \text { porke } & \text { kuando } & \varnothing \text {-tün-pa } & \text { y-tün-pü-pa } & \text { puro tumi'n } \\ \text { because } & \text { when } & \text { 3B-shit-ICP } & \text { 3A-shit-CL-ICP } & \text { pure money } \\ \text { 'Because when it shits, it shits pure money' (Historia 78) }\end{array}$

\section{Relative Clauses}

\subsection{External Relativization}

Relative clauses where a nominal element is relativized are formed by cliticizing the relativizer pü to the head of the clause. There is no relative pronoun or free complementizer word available for this function, and there is no trace of Spanish influence. When the relative construction has the role of a transitive subject in the matrix clause, the construction gets the ergative clitic, generally attached to the head noun -- henceforth referred to as the antecedent -- as in (26).

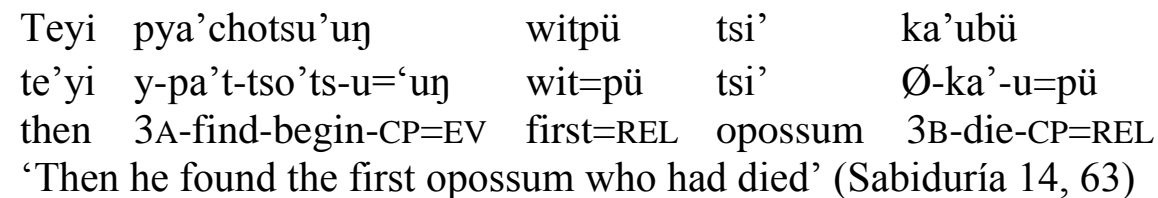

$\begin{array}{llllll}\text { Tü'ük } & \text { midupü } & \text { yomo'is } & \text { 'yispükpa } & \text { üj } & \text { nana } \\ \text { tü'ük } & \varnothing \text {-min-u=pü } & \text { yomo='is } & \text { y-'ispük-pa } & \text { üj- } \varnothing & \text { n-nana } \\ \text { yesterday } & \text { 3B-come-CP=REL } & \text { woman=ERG } & \text { 3A-know-ICP } & \text { PRO1-GEN } & \text { 1A-mother } \\ \text { 'The woman who came yesterday knows my mother' } & \end{array}$


As is common in relative constructions cross-linguistically, the relativized phrase - the shared element - is represented by an empty position inside the relative clause. In Zoque the case marker is a clitic, and this gives rise to a peculiar situation; in sentences where the relativized element has the role of a transitive subject within the relative clause, the case clitic does not disappear with the noun phrase; instead it is stranded inside the relative clause. Since it is a clitic, it needs a host, and attaches to the relativizer pü.

$$
\begin{array}{llllll}
\text { Mye'chajpa } & \text { tyüdam } & \text { makabü'is } & \text { ñütsüjkye } & \text { te’ } & \text { ku'tkuy } \\
\text { y-me'ts-yaj-pa } & \text { y-tü-tam } & \text { man-pa=pü='is } & \text { y-nütsük-yaj-E } & \text { te' } & \text { ku'tkuy } \\
\text { 3A-search-3PL-ICP } & \text { 3A-friend=PL } & \text { FUT-ICP=REL=ERG } & \text { 3A-make-3PL-DEP } & \text { DET } & \text { food }
\end{array}
$$

'They are looking for their friends who are going to help prepare the food' (Ocotepec)

In (27) the relativized phrase, tyüdam 'their friends', has the role of transitive subject in the relative clause, and would therefore have been in the ergative. The noun itself is omitted, as expected, but the ergative clitic 'is remains, added to the realtivizer pü, which itself is a clitic on the head of the relative clause, the future auxiliary maka, resulting in the complete auxiliary makabü'is.

The type of relative construction exemplified so far may be referred to as external relativization. The shared element is expressed as the head noun outside the relative clause, and its case marking depends on its function in the matrix clause.

\subsection{Internal Relativization}

In addition to the familiar external relativization type, Zoque also exhibits what may be called internal relativization. Here the shared element is overtly present inside the relative clause, and there is no overt antecedent outside. Cross-linguistically and typologically, languages seem to prefer one or the other of those two strategies (BIANCHI 1999, COLE 1987, COLE \& HERMON 1994, ÅFARLi 1994). Zoque seems to be quite unusual in that we find both strategies in one and the same language. Although external realtivization seems to be most common in written texts, speakers often produce internal relativization during elicitation.

The difference between the two relativization strategies in Zoque can best be seen when either the relative construction or the relativized element inside the clause has a function where it would be overtly case marked (i.e. in another case than the absolutive, which is zero marked). With internal relativization the shared element is case marked for the function that it has inside the relative clause, regardless of the function of the relative construction in the matrix clause. Contrast (26), repeated here as (28a), with external relativization, and (28b), with internal. (Both sentences are elicited from native speakers. The relative construction in each example is underscored).

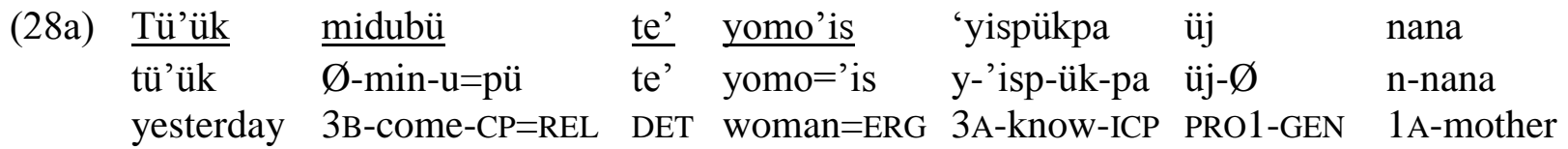
'The woman who came yesterday knows my mother' 


$\begin{array}{lllllll}\frac{\text { Te' }}{\text { yomo }} & \text { midubü } & \underline{\text { tü' üjk }} & \text { 'yispükpa } & \text { üj } & \text { nana } \\ \text { te' yomo } & \emptyset \text {-min-u=pü } & \text { tü'ük } & \text { y-'isp-ük-pa } & \text { üj- } \varnothing & \text { n-nana } \\ \text { DET } & \text { woman } & \text { 3B-come-CP=REL } & \text { yesterday } & \text { 3A-know-ICP } & \text { PRO1-GEN } & \text { 1A-mother } \\ \text { 'The woman who came yesterday } & \text { knows my mother' }\end{array}$

The two types of relativization can be illustrated as in (29a-b). Note that the relativizer pü is also a clitic, and attaches to the verb.

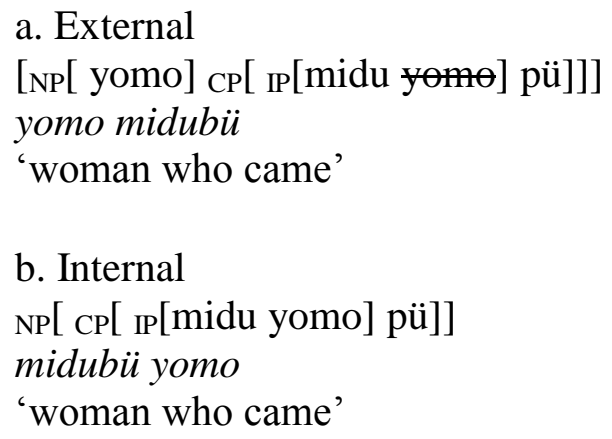

Internal relativization is particularly common in a type of cleft sentence. Zoque clefts are formed very much according to the same pattern as pseudo-clefts in English (FAARLUND 2007). An English pseudo-cleft sentence consists of a focused element, typically a DP, predicated of a relative clause: What I want is a horse. The difference is that Zoque does not have relative clauses introduced by wh-words or complementizers, and it lacks copula verbs. Non-verbal sentences are formed by adding the clitic te to the nominal predicate. ${ }^{3}$

$\begin{array}{lllll}\text { Te' } & \text { wi'nabü } & \text { testamentu } & \text { wi'nabü } & \text { odede } \\ \text { te' } & \text { wi'na=pü } & \text { testamentu } & \text { wi'na=pü } & \varnothing \text {-'ode=te } \\ \text { DET } & \text { old=REL } & \text { testament } & \text { old=REL } & \text { 3B-word=PRED }\end{array}$

'The old testament is the old word' (Ocotepec)

Cleft sentences are then formed by adding the predicate clitic to the clefted element, and adding a relative clause. The clefted element has the case required by its function in the relative clause, in other words, internal relativization.

$\begin{array}{lllll}\text { Te'iste } & \text { makabü } & \text { chükye } & \text { te' } & \text { sük } \\ \emptyset \text {-te'='is=te } & \text { may-pa=pü } & \text { y-tsük-yaj-E } & \text { te' } & \text { süy } \\ \text { 3B-DET=ERG=PRED } & \text { FUT-ICP=REL } & \text { 3A-make-3PL-DEP } & \text { DET } & \text { fiesta } \\ \text { 'It is they who will make the fiesta' } & \text { (Ocotepec) } & & \end{array}$

${ }^{3}$ Originally, and still occasionally, non-verbal clauses were formed by simply juxtaposing the subject and the predicate. Non-verbal predicates are intransitive, so the subject would be in the absolutive and follow the verb, according to the general principles of unmarked word order in Zoque. Eventually the determiner $t e$ ', which would serve as a postposed subject, was grammaticalized and became a clitic, added to the predicate word. 


$$
\begin{array}{lll}
\text { Yempe } & \text { isuyde } & \text { iyijspabü } \\
\text { yempe } & \mathrm{i}=\text { 'is=uy=te } & \text { y-'is-pa=bü } \\
\text { any } & \text { some=ERG=EV=PRED } & \text { 3A-see-ICP=REL }
\end{array}
$$

'There were many who saw her' (Bolom 267)

In (31) te' is the clefted or focused element. Although it is the subject of an intransitive nominal predicate, it carries the ergative marker 'is, the reason being that it is the subject of a transitive verb in the relative clause. Similarly in (32), the word for 'some', $i$ (which in combination with the general quantifier yempe means 'many') has the ergative clitic added to it because it is also the subject of 'see'.

If the internal relative construction has the role of transitive subject in the matrix clause, it may optionally carry the ergative clitic.

$$
\begin{array}{lllllll}
\text { Te' } & \text { tsü'yubüis } & \text { najayu'ujn } & \text { te' } & \text { kotsüjk } & \text { wa'a } & \text { ianga'mu } \\
\text { te' } & \varnothing \text {-tsü'y-u=pü='is } & \text { y-na-jay-u='uy } & \text { te' } & \text { kotsük } & \text { wa'a } & \text { y-'anga'm-u } \\
\text { DET } & \text { 3B-stay-CP=REL=ERG } & \text { 3A-tell-APP-CP=EV } & \text { DET } & \text { mountain } & \text { SC } & \text { 3A-close-sUB } \\
\text { 'The one who stayed told the mountain to close itself' (Historia 72) } & &
\end{array}
$$

Here an ergative clitic is added to the entire clause, te' ts $\ddot{u}$ 'yubü; this clause functions as the subject of the matrix transitive clause. Instead of a relative clause adjoined to a head noun as an antecedent, the head noun is inside the relative clause. The result is a monoclausal construction, with a stronger cohesion between the head and the rest of the clause.

I have no certain data on the history of the monoclausal relatives, except that I have not been able to find any examples of such constructions in older documents. It would be plausible, however, to consider them instances of a development towards stronger cohesion, considering that in such a monoclausal construction the break between the head and its complement is abolished.

\subsection{Focus Constructions}

The clefted elements described in the previous section as non-verbal predicates with the predicator clitic te, are marked as focus elements. In such a construction the relativizer pü may be omitted. There is then nothing left to mark the structure as biclausal. The focused element is left with the original predicator as a pure focus marker.

$$
\begin{array}{lllll}
\text { Chamjayu'un } & \text { te' } & \text { gyomo } & \text { tiyüte } & \text { tuku } \\
\text { y-tsam-jay-u='un } & \text { te' } & \text { y-yomo } & \text { tiyü'=te } & \emptyset \text {-tuk-u } \\
\text { 3A-tell-APP-CP=EV } & \text { DET } & \text { 3A-wife } & \text { what=PRED } & \text { 3B-happen-CP } \\
\text { 'He told his wife what happened' (Historia 221) } &
\end{array}
$$

As the next step, the focus marker te can be used with any phrase type, such as an interrogative word, (35), or even a verb, (36). (For more details, see FAARLUND 2007). 
(35)

$\begin{array}{lll}\text { Tiyande } & \text { oyu } & \text { muki? } \\ \text { tiyam=te } & \text { oy-u } & \text { m-muk-E } \\ \text { what=FOC } & \text { TER-CP } & \text { 2A-measure-DEP }\end{array}$

'What are you measuring?' (Historia 70)

$\begin{array}{ll}\text { Kejkunde } & \text { najsomo } \\ \varnothing-\text {-kek- } \mathrm{u}={ }^{\prime} \mathrm{u} u=\text { te } & \text { nas='omo } \\ \text { 3B-fall- } \mathrm{CP}=\mathrm{EV}=\mathrm{FOC} & \text { ground=LOC }\end{array}$

'He fell to the ground' (Sabiduría 8, 10)

\section{Discussion and Conclusion}

Zoque is a language with a very recent history of literacy, and very few of its speakers are literate in their own language. Its structure and complexity can therefore be assumed to be that of a non-literate language. This is in contrast to a widespread assumption even among professional linguists that literacy increases syntactic complexity (as an example of this view, see several of the papers in SAMPSON et al. 2009). We have seen above that the language has - and has had since the time of colonization - syntactic resources for various degrees of complexity. The language exhibits a wide variety of subordination strategies, from simple juxtaposition with no overt complementizer, through independent complementizer words and wh-words, to cliticized complementizers. As an endpoint we may consider the monoclausal relative constructions which have developed into focus constructions.

None of this variety is due to influence from the colonizer language. There has been a certain Spanish influence in parts of the grammar of embedding, mainly in terms of lexical items, but it is not possible to say that this influence has lead to a higher degree of grammatical cohesion. The Spanish influence on Zoque dependent clause constructions has not significantly changed already existing patterns. With the exception of the conjunction $i$, which had no equivalent in the precolonial language, the influence is limited to expanding the inventory of complementizer words. We have no clear evidence in support of the often-made claim of a correlation between the depth of embedding or clause cohesion and the degree of literacy.

\section{Spelling Convention}

Most of the letters have the expected value corresponding to Spanish orthography, but note in particular:

The vowels <a, e, i, o, u> always have the short value and are pronounced close to the Spanish equivalents. $\langle\ddot{u}\rangle$ is a mid central vowel $[\Lambda]$. $\langle\mathrm{y}\rangle$ and $\langle\mathrm{w}\rangle$ are semivowels.

$\langle\mathrm{g}\rangle$ is always a voiced stop.

$<\mathrm{ch}>$ is an affricate, as in English and Spanish.

$<\mathrm{x}>$ is $[\check{\mathrm{s}}$.

$\langle\mathrm{j}\rangle$ is $[\mathrm{h}]$.

$<>$ is a glottal stop. 


\section{Abbreviations}

1: $1^{\text {ST }}$ PERSON; 2: $2^{\mathrm{ND}}$ PERSON; 3: $3^{\mathrm{RD}}$ PERSON; 1ABS: 1st person absolutive; 1ERG: 1st person ergative; 1I: 1st person inclusive; A: series A prefix; B: series B prefix; C: complementizer; CAUS: causative prefix; CL: completely; COM: comitative case; CP: completive aspect; CSUB: causal subordinative; DEP: dependent verb; DET: determiner; ERG: ergative case; EV: evidential; FUT: future auxiliary; GEN: genitive; ICP: incompletive aspect; INC: inchoative auxiliary; INCV: inchoative verbal suffix; NEG: negation; IPL: 1st person inclusive plural; LIM: limitational; LOC: locative case; PAS: passive; PERF: perfective aspect; PG: progressive suffix; PL: plural; PRED: predicator; PRG: progressive preverb; PRO: pronoun; PROI: 1st person inclusive pronoun; PRX: proximal demonstrative; PST: past; REL: relativizer; REP: repetitive; SC: subjunctive complementizer; SIM: similative case; SUB: subjunctive; TER: terminative auxiliary; TSUB: temporal subordinative; v: verbalizer

In the glossses, a hyphen '-' separates affixes and compounds, an equal sign '=' separates clitics from their host.

\section{Sources}

Bolom Y $\quad Y$ el Bolom dice ... Antología de cuentos, vol. II. Gobierno del Estado de Chiapas, 2000.

Cuentos Cuentos y relatos indígenas. Vol. 6. Universidad Nacional Autónoma de México, 1997.

Gramática Gramática de la lengua zoque. Gobierno del estado, Tuxtla Gutiérrez, Chiapas.

Historia Silvia Perez Bravo, Sergio Lopez Morales: Breve historia oral zoque. Gobierno del Estado, Chiapas. 1. ed. 1985.

Kak Y te’ kak nümba. Seleccción de cuentos zoques. Gobierno del Estado de Chiapas, 2001.

Ocotepec Recording made by the author in the village of Ocotepec, December 1996.

Sabiduría Nuestra sabiduría. CELALI y Unidad de Escritores Mayas-Zoques.

Where no source is given, the example has been elicited from Zoque speakers from Ocotepec or Tapalapa.

\section{References}

Åfarli, Tor A. 1994. A promotion analysis of restrictive relative clauses, in The Linguistic Review 11, 81-100.

Bianchi, Valentina. 1999. Consequences of Antisymmetry. Headed Relative Clauses. Berlin: Mouton de Gruyter.

Cole, Peter. 1987. The structure of internally headed relative clauses, in: Natural Language and Linguistic Theory 5, 288-302.

Cole, Peter \& Hermon, Gabriela. 1994. Is there LF Wh-movement?, in: Linguistic Inquiry 25, 239-262.

Faarlund, Jan T. 2004. Clitics and morphological categories in Zoque. CLS 38-2: The Panels. 
Proceedings from the Panels of the Thirty-eighth Meeting of the Chicago Linguistic Society, ed. by Mary Andronis, Erin Debenport, Ann Pycha, and Keiko Yoshimura, 341-7. Chicago: Chicago Linguistic Society.

-----. 2007. From Cleft Sentence to Morphological Focus Marker in Zoque. Interpreting Utterances: Pragmatics and its Interfaces. Essays in honour of Thorstein Fretheim, ed. by Randi A Nilsen, Nana Aba Appiah Amfo, and Kaja Borthen, 221-230. Oslo: Novus.

-----. 2010. Review of Sampson et al. 2009. Language 86, 748-752.

-----. 2011. A Grammar of Chiapas Zoque. Oxford: Oxford University Press.

Sampson, Geoffrey. 2009. A linguistic axiom challenged. Sampson et al. 2009, 1-18.

Sampson, Geoffrey, David Gil, and Peter Trudgill (eds.) 2009. Language Complexity as an Evolving Variable. Oxford: Oxford University Press.

Author's Contact Information:

Jan Terje Faarlund

Centre for the Study of Mind in Nature

P.O. Box 1020 Blindern

NO-0315 Oslo

Norway

j.t.faarlund@iln.uio.no 